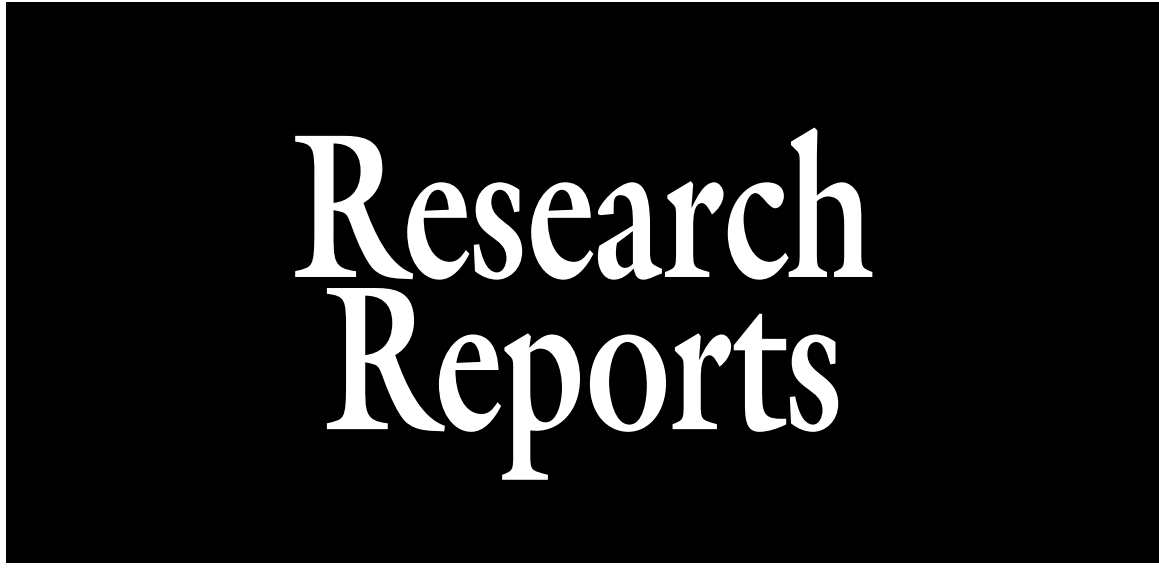

\title{
An Assessment of Organic Apple Production in Kentucky
}

\author{
Mark A. Williams ${ }^{1}$, John G. Strang ${ }^{1}$, Ricardo T. Bessin ${ }^{2}$, \\ Derek Law ${ }^{1}$, Delia Scott ${ }^{1}$, Neil Wilson ${ }^{1}$, Sarah Witt ${ }^{3}$, and \\ Douglas D. Archbold ${ }^{1,4}$
}

AdDitional IndeX wORDs. Malus $\times$ domestica, fruit thinning, tree growth, diseases, insects

\begin{abstract}
SUMmARY. Although the interest in and production acreage of organic fruit and vegetables has grown in recent years, there are questions about the viability of perennial crops such as apple (Malus $\times$ domestica) in an organic system in Kentucky because of the long, hot, and humid growing season. Thus, the objective of this project was to assess the severity of the challenges to organic apple production in Kentucky. A high-density, organic apple orchard was established in 2007 in the University of Kentucky Horticultural Research Farm in Lexington. The orchard of apple scab (Venturia inaequalis)-resistant 'Redfree', 'Crimson Crisp', and 'Enterprise' trees on 'Budagovsky 9' (B.9) rootstock, trained in a vertical axis system, was managed using organically certified techniques and materials for disease and insect control since its inception. Tree growth, tree and fruit injury from insect pests and diseases, and yield over the period 2011-13 were studied. Periodic, shallow cultivation kept the ground beneath the trees free of vegetation once the lower limbs were pulled up and away from the path of the equipment. Vole (Microtus sp.) damage was a continuing problem despite the use of trunk guards and cultivation to remove habitat around the trees. Total fruit yield ranged from 1.2 to $8.1 \mathrm{~kg} /$ tree across years and cultivars, with the marketable proportion of the total yield averaging $68 \%$ for Redfree and $43 \%$ for Crimson Crisp and Enterprise over the 3-year period. The unmarketable fruit exhibited a high incidence of plum curculio (Conotrachelus nenuphar) damage, with generally less damage from codling moth (Cydia pomonella) and sooty blotch (Glosodes pomigena)/flyspeck (Schizathyrium pomi . In addition, in two of the three seasons, 'Crimson Crisp' and 'Enterprise', which were harvested at later calendar dates then 'Redfree', had significant levels of powdery mildew (Podosphaeva leucotricha) injury, 'Enterprise' had significantly greater bitter rot (Glomevella cingulata), and 'Crimson Crisp' showed fruit and foliar damage from cedar apple rust (Gymnosporangium juniperi-virginianae). Because 'Redfree' was the only cultivar with an acceptable marketable proportion of the fruit crop, the use of early ripening disease-resistant apple cultivars may have the greatest potential for successful organic apple production in Kentucky and the surrounding region.
\end{abstract}

$\mathrm{N}$ ationally, the production of organically grown apples increased from 2000 to 2008 (Slattery et al., 2011) but has more recently declined (Perez and Plattner,
2013). Organic apple production comprises only $3 \%$ of the total apple acreage in the United States, and most of it is located in Washington state where climate and low pest pressure are most favorable. As local markets and the interest in organic production of fruits and vegetables grow (Low and Vogel, 2011), local organic growers in Kentucky are seeking to diversify the crops they grow to address consumer interest. Apples have traditionally been a popular locally grown product, but commercial organic apple production has significant financial risk due to the high costs of establishment, the delay in time until fruit production, and unknown fruit yield and quality and price premiums. Several growers in Kentucky have tried organic apple production in recent years but have been unsuccessful (J. Strang, personal communication). At present, there is no commercial organic apple production in Kentucky.

Recent organic apple production studies in Michigan (Stefanelli et al., 2009), New York (Peck et al., 2010), Iowa (Delate and Friedrich, 2004; Delate et al., 2008; Friedrich et al., 2003), Vermont (Berkett et al., 2012), and Arkansas (Aselage and Johnson, 2009; Johnson et al., 2010) have identified some of the major problems confronting organic apple production in the eastern United States. In Iowa, less than $25 \%$ of the leaves and fruit of apple scab-resistant cultivars exhibited disease or insect injury in a certified organic apple orchard. Quince rust (Gymnosporangium clavipes) caused the most damage, whereas damage from the major insect pests, codling moth and plum curculio, was less than $10 \%$. In New York, significant year-toyear variation in disease and insect injury was evident, although the proportion of unmarketable fruit was less than $10 \%$ in all but one season (Peck et al., 2010). Lepidoptera, including codling moth, and the sooty blotch/ flyspeck disease complex were the most significant problems noted, though not in all seasons. The results of several pest management studies in Arkansas suggested that current Organic Materials Review Institute (OMRI)-approved materials (OMRI, 2014) may be sufficient for control of insect injury (Aselage and Johnson, 2009; Johnson et al., 2010).

Like Arkansas, Kentucky has a longer growing season than the other locations cited above, with higher seasonal mean temperatures and humidity. These conditions can foster more generations of insect pests such as codling moth, and more 
frequent conditions favoring disease development than in more northerly areas (Aselage and Johnson, 2009). At the inception of this project, there were no research studies from Kentucky or adjacent states that had assessed the severity of the known challenges to organic apple production (Hinman and Ames, 2011) or the effectiveness of recommended OMRI-approved pest and disease management tools. The severity of the challenges when managed with the available tools need to be clearly characterized first, so that management strategies can be studied and/or developed. As new technologies emerge, they may make organic apple production increasingly possible. To determine the feasibility of, and identify specific challenges to, organic apple production in Kentucky, a high-density, organic apple orchard was established in 2007 at the University of Kentucky Horticultural Research Farm in Lexington. The study was conceived as having two phases. In Phase 1 , covering planting through the first 3 years of fruit production (2011-13) and reported here, the orchard of apple scab-resistant trees was managed using organically certified techniques and materials for fertility, and disease, insect, and weed control, to assess tree growth, tree and fruit injury from insect pests and diseases, and yield. In Phase 2, beginning in 2014, strategies to address major limitations and/or problems identified in Phase 1 will be tested.

\section{Materials and methods}

This study was conducted at the University of Kentucky Horticulture Research Farm in Lexington, KY (lat. $37^{\circ} 58^{\prime} 24^{\prime \prime} \mathrm{N}$, long. $84^{\circ} 32^{\prime} 5^{\prime \prime} \mathrm{W}$ ), on a site previously in fescue (Festuca sp.) for many years, and which had been managed according to U.S. Department of Agriculture (USDA) National

Funding for this project was provided by a New Crop Opportunities Grant from 2006 to 2009 and a Specialty Crop Block Grant from 2010 to 2013 by the Kentucky Department of Agriculture.

We thank Dr. John Hartman and Dr. Nicole Ward Gauthier (Department of Plant Pathology, University of Kentucky) for their contributions to the development of disease management spray schedules for this project.

${ }^{1}$ Department of Horticulture, University of Kentucky, Lexington, KY 40546

${ }^{2}$ Department of Entomology, University of Kentucky, Lexington, KY 40546

${ }^{3}$ Department of Statistics, University of Kentucky, Lexington, KY 40536

${ }^{4}$ Corresponding author. E-mail: darchbol@uky.edu.

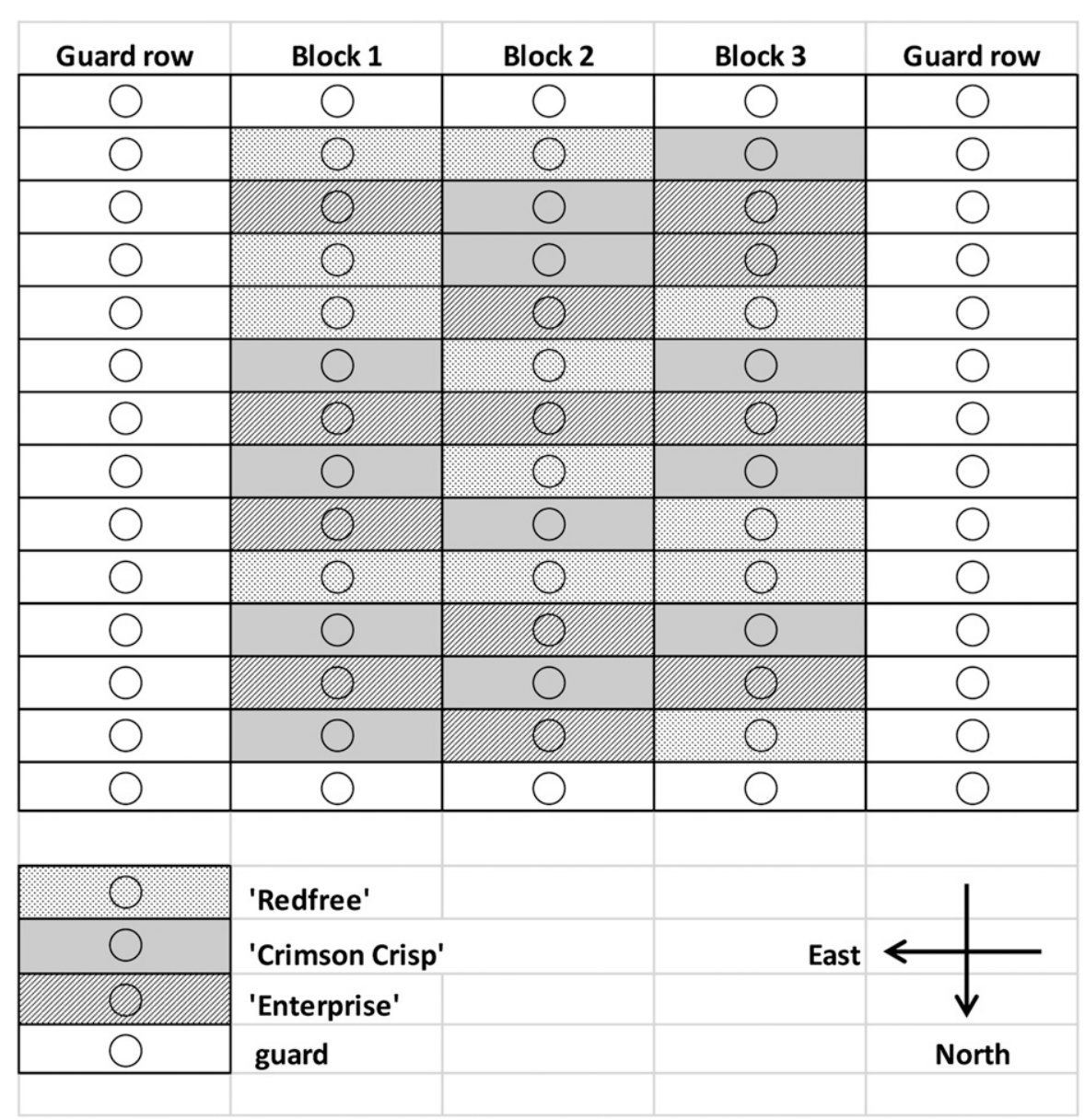

Fig. 1. Diagram of plot design of organically grown apples at the Horticultural Research Farm, Lexington, KY. Each cell for a cultivar represents three trees, an individual replicable unit.

Organic Program guidelines for 5 years (USDA-certified organic for 2 years). The soil was a Bluegrass Maury silt loam, fine, mixed, active, mesic typic paleudalfs (USDA classification). In June 2006, five north-south rows, $12-\mathrm{ft}$ wide, $275-\mathrm{ft}$ long, on $18-\mathrm{ft}$ centers, were tilled, and the beds were shallow cultivated with a field cultivator about every 2 weeks from June until November to create stale seedbeds and reduce weed seeds in the upper layers of the soil. Soils, sampled in Aug. 2006, had a pH of 5.8. Thus, lime was applied at a rate of 4 tons/ acre in Nov. 2006 to raise the $\mathrm{pH}$ to 6.8. Manure-based compost from the University of Kentucky Woodford County Beef Unit was also applied at a rate of 25 tons/acre to only the tilled strips.

In Apr. 2007, trees of the apple scab-resistant cultivars Redfree, Crimson Crisp, and Enterprise on Budagovsky 9 (B.9) rootstock were planted in three rows in the tilled beds. Each row

\begin{tabular}{llll}
\hline $\begin{array}{l}\text { Units } \\
\begin{array}{l}\text { To convert U.S. to SI, } \\
\text { multiply by }\end{array}\end{array}$ & U.S. unit & SI unit & $\begin{array}{l}\text { To convert SI to U.S., } \\
\text { multiply by }\end{array}$ \\
\hline 73.0778 & $\mathrm{fl} \mathrm{oz} / \mathrm{acre}$ & $\mathrm{mL} \cdot \mathrm{ha}^{-1}$ & 0.0137 \\
0.3048 & $\mathrm{ft}$ & $\mathrm{m}$ & 3.2808 \\
9.3540 & $\mathrm{gal} / \mathrm{acre}$ & $\mathrm{L} \cdot \mathrm{ha}^{-1}$ & 0.1069 \\
2.54 & inch $(\mathrm{es})$ & $\mathrm{cm}$ & 0.3937 \\
6.4516 & inch2 & $\mathrm{cm}^{2}$ & 0.1550 \\
0.4536 & $\mathrm{lb}$ & $\mathrm{kg}$ & 2.2046 \\
1.1209 & $\mathrm{lb} / \mathrm{acre}$ & $\mathrm{kg} \cdot \mathrm{ha}^{-1}$ & 0.8922 \\
28.3495 & $\mathrm{oz}$ & $\mathrm{g}$ & 0.0353 \\
1 & $\mathrm{ppm}$ & $\mathrm{mg} \cdot \mathrm{L}^{-1}$ & 1 \\
2.2417 & ton $(\mathrm{s}) / \mathrm{acre}$ & $\mathrm{Mg} \cdot \mathrm{ha}^{-1}$ & 0.4461 \\
$\left({ }^{\circ} \mathrm{F}-32\right) \div 1.8$ & ${ }^{\circ} \mathrm{F}$ & ${ }^{\circ} \mathrm{C}$ & $\left({ }^{\circ} \mathrm{C} \times 1.8\right)+32$
\end{tabular}


contained four randomly arranged blocks of three trees of each cultivar per block with guard trees at both ends of each row and a guard row of trees on the east and west sides of the three research rows (Fig. 1). The guard trees were composed of a large number of disease-resistant varieties. Trees were set at $6 \times 18$-ft spacing within and between rows, respectively, for a density of 400 trees/acre. Trickle irrigation was installed soon after planting, suspended on stakes to allow cultivator access. Tree guards were placed around each trunk to deter rodents. A grass groundcover was established between rows in September, consisting of creeping red fescue (Festuca rubra) at $8 \mathrm{lb} / \mathrm{acre}$, subterranean clover (Trifolium subterraneum 'Dalkeith' and 'Gosse') at $20 \mathrm{lb} /$ acre, and a low-growing wildflower mix at $10 \mathrm{lb} /$ acre (Peaceful Valley, Grass Valley, CA). The ground beneath the trees was cultivated once in the early spring, twice in the summer as needed, and once in the fall after harvest with an inrow tiller (4000-NST; Weed Badger, Marion, ND) to a depth of 2-4 inches and a swath $2 \mathrm{ft} 7$ inches wide on each side of the tree row, followed by hand hoeing to remove vegetation near the base of the trees.

Each tree was staked to a metal T-post (12-ft long, set about $2-\mathrm{ft}$ deep) in 2007. Trees were pruned to a vertical axis system until year 6 (2012). In 2012, a trellis wire $3 \mathrm{ft}$ above the ground was attached to the posts, and the lower branches were tied to it using rubber bands. This prevented lower branches, often pulled too far downward due to their fruit load, from impeding cultivation. In 2013, an upper wire was attached $5 \mathrm{ft} 7$ inches above the ground, and upper branches were attached to it.
To sustain sufficient vegetative growth on the upper trellis wire while carrying a fruit crop, and with concerns about unknown rates of nitrogen (N) loss by leaching and immobilization, trees were fertilized with 100 $\mathrm{lb} /$ acre actual $\mathrm{N}(4 \mathrm{oz} /$ tree actual $\mathrm{N})$ each spring $[10 \mathrm{~N}-4.4 \mathrm{P}-8.3 \mathrm{~K} 2007-$ $12,10 \mathrm{~N}-0.9 \mathrm{P}-6.6 \mathrm{~K}$ in 2013 (Nature Safe Natural \& Organic Fertilizers, Cold Spring, KY)], a per tree rate ( $1 \mathrm{oz} /$ year of tree age in 2011) within the range of that used in conventionally managed orchards (Bessin et al., 2011). The orchard was sprayed with OMRIapproved pesticides, which were reported and/or recommended for controlling the major apple diseases and insect pests (Table 1). An air-blast poly tank sprayer (DP100; DurandWayland, LaGrange, GA) was used to apply all spray applications as a dilute spray at $100 \mathrm{gal} / \mathrm{acre}$. In addition, NoMate codling moth lures (Scentry

Table 1. Organic Materials Review Institute-approved compounds used for disease and insect control of organically grown apples at the Horticultural Research Farm, Lexington, KY, in 2011-13.

Problems

Rate and compound (trade name, active ingredient; source) ${ }^{\mathrm{z}}$

Diseases

Fire blight

Apple scab, cedar apple rust, bitter rot, black rot/frogeye leaf spot, sooty blotch/flyspeck, powdery mildew

Insects

San jose scale

Plum curculio, codling moth, oriental fruit moth

Green apple aphid, tarnished plant bug, red-banded leaf roller, oblique-banded leaf roller, fruit-tree leaf roller, green stink bug, brown stink bug, brown marmorated stink bug

Dogwood borer

Fruit thinning
$4.2 \mathrm{lb} /$ acre fixed copper (Nordox $75 \mathrm{WG}, 83.9 \%$ cuprous oxide; Nordox, Oslo, Norway)

22 ppm streptomycin (Agri-Mycin 17, 22\% streptomycin sulfate; Nufarm Americas, Burr Ridge, IL)

$4.8 \mathrm{lb} /$ acre wettable sulfur (Microthiol Disperss, $80 \%$ sulfur; United Phosphorus, King of Prussia, PA)

$1.1 \mathrm{gal} /$ acre liquid lime sulfur (Green Cypress lime-sulfur solution, 29\% calcium polysulfide; Monterey AgResources, Fresno, CA)

Fixed copper (as above)

$1.6 \mathrm{fl} \mathrm{oz} /$ acre giant knotweed (Reynoutria sachalinensis) extract (Regalia, 5\% a.i.; Marrone Bio Innovations, Davis, CA)

$2.5 \mathrm{lb} /$ acre potassium bicarbonate (Kaligreen, 82\% a.i.; Otsuka Chemical Co., Osaka, Japan)

2.9 gal/acre dormant oil (Damoil, 98\% mineral oil; Drexel Chemical Co., Memphis, TN)

$1.3 \mathrm{fl} \mathrm{oz} /$ acre spinosad (Entrust, $80 \%$ a.i.; Dow AgroSciences, Indianapolis, IN)

$23.8 \mathrm{lb} /$ acre kaolin clay powder (Surround, 95\% a.i.; Tessenderlo Kerley, Phoenix, AZ)

$0.13 \mathrm{fl} \mathrm{oz} /$ acre granulosis virus (Cydia pomonella) (Carpovirusine, $0.99 \%$ a.i.; Arysta

LifeScience, Cary, NC)

$1.05 \mathrm{gal} /$ acre neem oil (Trilogy, 70\% clarified hydrophobic extract; Certis USA, Columbia, MD)

(E,E)-8,10-Dodecadien-1-ol (Codling moth pheromone mating disruption lures, $10.8 \%$ a.i.; Scentry Biologicals, Inc., Billings, MT)

$0.8 \mathrm{fl} \mathrm{oz} /$ acre pyrethrum (PyGanic, 5\% pyrethrins; MGK, Minneapolis, MN)

Parasitic nematodes (NemaSeek, H. bacteriophora; Arbico Organics, Oro Valley, AZ)

$2.5 \% \mathrm{v} / \mathrm{v}$ of both liquid lime sulfur (above) and fish oil/sesame oil (Organocide, 95\% fish oil $/ 5 \%$ sesame oil; Organic Laboratories, Stuart, FL)

${ }^{2} \mathrm{llb} / \mathrm{acre}=1.1209 \mathrm{~kg} \cdot \mathrm{ha}^{-1} ; \mathrm{l} \mathrm{ppm}=1 \mathrm{mg} \cdot \mathrm{L}^{-1} ; \mathrm{l} \mathrm{gal} /$ acre $=9.3540 \mathrm{~L} \cdot \mathrm{ha}^{-1} ; \mathrm{l} \mathrm{fl} \mathrm{oz} /$ acre $=73.0778 \mathrm{~mL} \cdot \mathrm{ha}^{-1}$. 
Biologicals, Billings, MT) were placed in the orchard in mid-June, and the parasitic nematodes Heterorbabditis bacteriophora were sprayed on the tree trunks to control dogwood borers (Synanthedon scitula) in July. Table 2 lists the sequence and timing of the sprays.

Fruit were thinned by spraying a mixture of liquid lime sulfur plus 95\% fish oil/5\% sesame oil [(LLS/ $\mathrm{FO}+\mathrm{S}$ (Organocide; Organic Laboratories, Stuart, FL)], each at $2.5 \%$ $\mathrm{v} / \mathrm{v}$, using an air-blast sprayer, at the completion of petal fall of 'Redfree' and 'Enterprise'. 'Crimson Crisp' was still in petal fall and also exhibited an extended bloom of later flowers from axillary buds, so the thinning treatment was not optimally timed for this cultivar. Because of the close proximity of the rows and relatively small size of the orchard, it was not possible to escape some drift from air-blast application between treated and untreated areas for a statistically appropriate experimental design, so the LLS/ $\mathrm{FO}+\mathrm{SO}$ was applied to either the north half or the south half of the orchard only. Before fruit thinning, five trees of each cultivar were randomly selected in the north half of the orchard, spread across rows, and five were chosen in the south half. Those in the untreated half were beyond the distance that drift may have occurred. The number of flower clusters on two tagged branches per tree ( 10 trees per cultivar) was counted. About 3 weeks after the thinning application, when fruitlet abscission appeared to be complete, the number of remaining fruitlets on each tagged branch was counted. Fruit per 100 flower clusters for each branch was calculated from the counts, and tree means were derived. All trees were then hand thinned, leaving one fruit per $15-25 \mathrm{~cm}$ of shoot length. Flower/fruitlet injury from a spring frost during bloom in 2012 was observed, but the thinning treatment was applied nonetheless since the degree of injury was unclear at the time.

Tree growth was assessed by measuring trunk diameter and terminal shoot length each year since 2009 . Trunk diameter was measured on dormant trees in the early spring at a height of $25 \mathrm{~cm}$ above the graft union. Trunk cross-sectional area (TCSA) was then calculated from trunk diameter as TCSA $=3.14 \times$ (diameter $/ 2)^{2}$. The terminal shoot length from growth the prior season was measured on three scaffold branches per tree in early spring before pruning, and an average per tree was calculated.

Fruit were harvested by hand starting when the first fruit drop was evident from a cultivar. The total yield was recorded for each tree, and fruit were placed in $39{ }^{\circ} \mathrm{F}$ storage. On completion of harvest of each cultivar, fruit were removed from cold storage and all were evaluated for marketability. Fruit were considered marketable if they had healed disease or insect injuries covering $<25 \%$ of the fruit surface, had no deformity, exhibited $<50 \%$ russeting, and were $>5.7 \mathrm{~cm}$ in diameter. Fruit count was obtained for both yield categories, and mean fruit weight per category was calculated by dividing yield by fruit count. Individual fruit were also examined for signs of insect and/or disease injury, and the number of fruit with plum curculio, codling moth, san jose scale (Quadraspidiotus perniciosus), oriental fruit moth (Grapholita molesta), green stink bug (Acrosternum hilare), brown stink bug (Euschistus servus), brown marmorated stink bug (Halyomorpha halys), green apple aphid (Aphis pomi), tarnished plant bug (Lygus lineolaris), red-banded

Table 2. The organic apple spray schedule at the Horticultural Research Farm, Lexington, KY, in 2013.

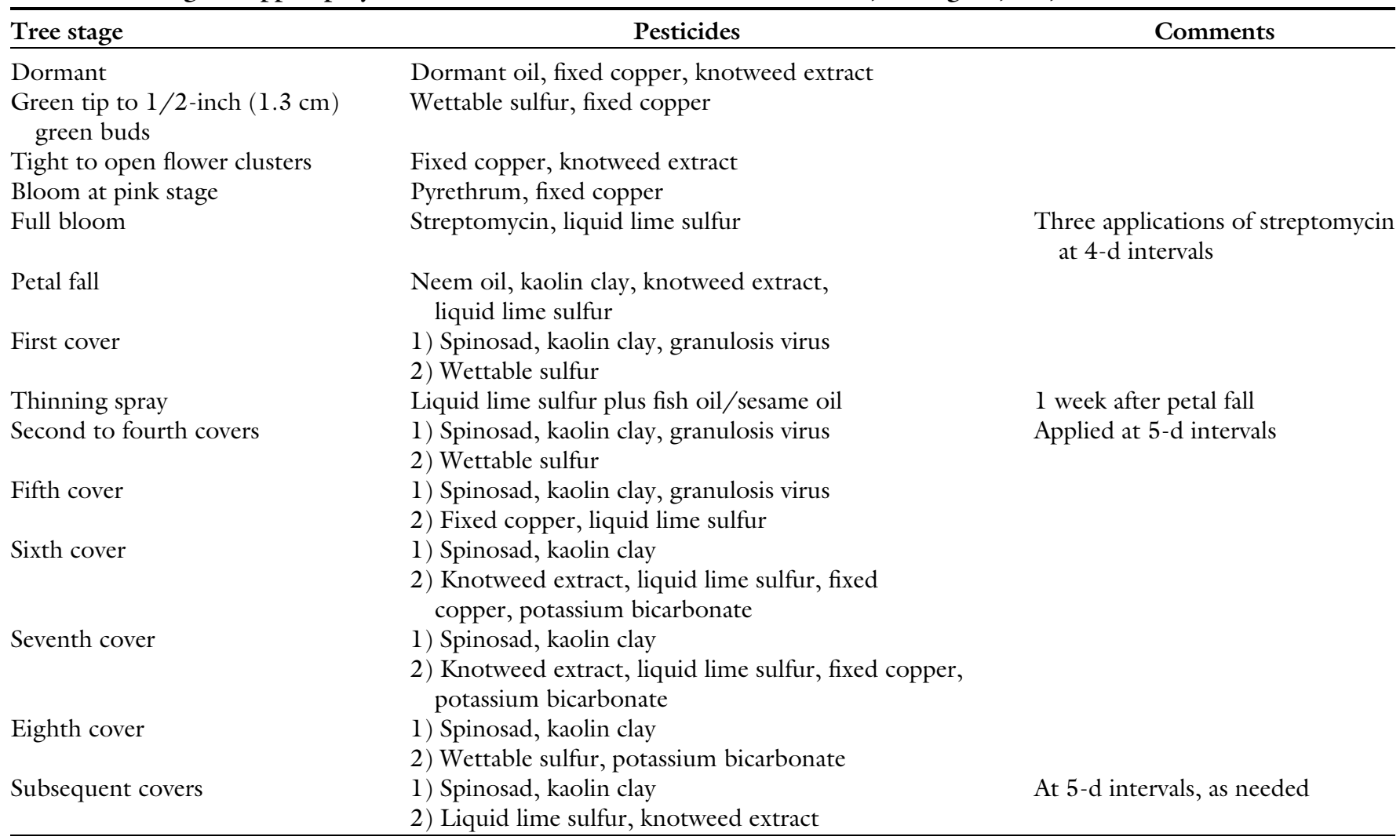


leaf roller (Argyrotaenia velutinana), oblique-banded leaf roller (Choristoneura rosaceana), and fruit-tree leaf roller (Archips argyrospila) injury, and evidence of cedar apple rust, powdery mildew, apple scab, sooty blotch/ flyspeck, bitter rot, and black rot/ frogeye leaf spot (Botryosphaeria obtusa) was recorded. An individual fruit could display signs of more than one problem, and if so was recorded in each category.

Observations in 2009-10 indicated that 'Crimson Crisp' was the only one of the three cultivars susceptible to foliar injury from cedar apple rust. Thus, after harvest each year, cedar apple rust severity was assessed on six randomly chosen 'Crimson Crisp' trees. On each tree, the total number of leaves was counted on six shoots, and the number of leaves with lesions and lesions per leaf were recorded. From this data, the mean percentage of leaves with lesions and lesions per leaf were calculated. Coincident examination of 'Redfree' and 'Enterprise' trees revealed no significant leaf injury from cedar apple rust, thus leaves were not sampled.

Tree death in the orchard was recorded each year, and the probable cause was noted if evident.

Each group of three adjacent trees of a cultivar was considered as one replicable unit. The means of the three trees (or two if one of the original three trees was missing and/or had been re-planted) within a replicable unit were derived and used as the replicate value for each measured trait. Each complete row was considered one block. Within each block, there were four randomly arranged replicable units of each cultivar (Fig. 1). Percent values were transformed by the arcsine (square root) function before analysis of variance (ANOVA) using SAS (version 9.3; SAS Institute, Cary, NC), with least squares (LS) means of nontransformed data shown. Cultivar LS means were compared within years by pdiff at $P<0.05$. As noted above, the fruit thinning treatments were not replicated appropriately, so only the means \pm SE are reported.

\section{Results and discussion}

The statistical analyses indicated significant differences between years, by cultivar, and for the cultivar by year interaction for all traits at $P<0.05$. The cultivar by year interaction was due primarily to the frost event that affected the cultivars differently because of their stage of bloom at the time of the event. Thus, the data are presented for comparing cultivars within years only.

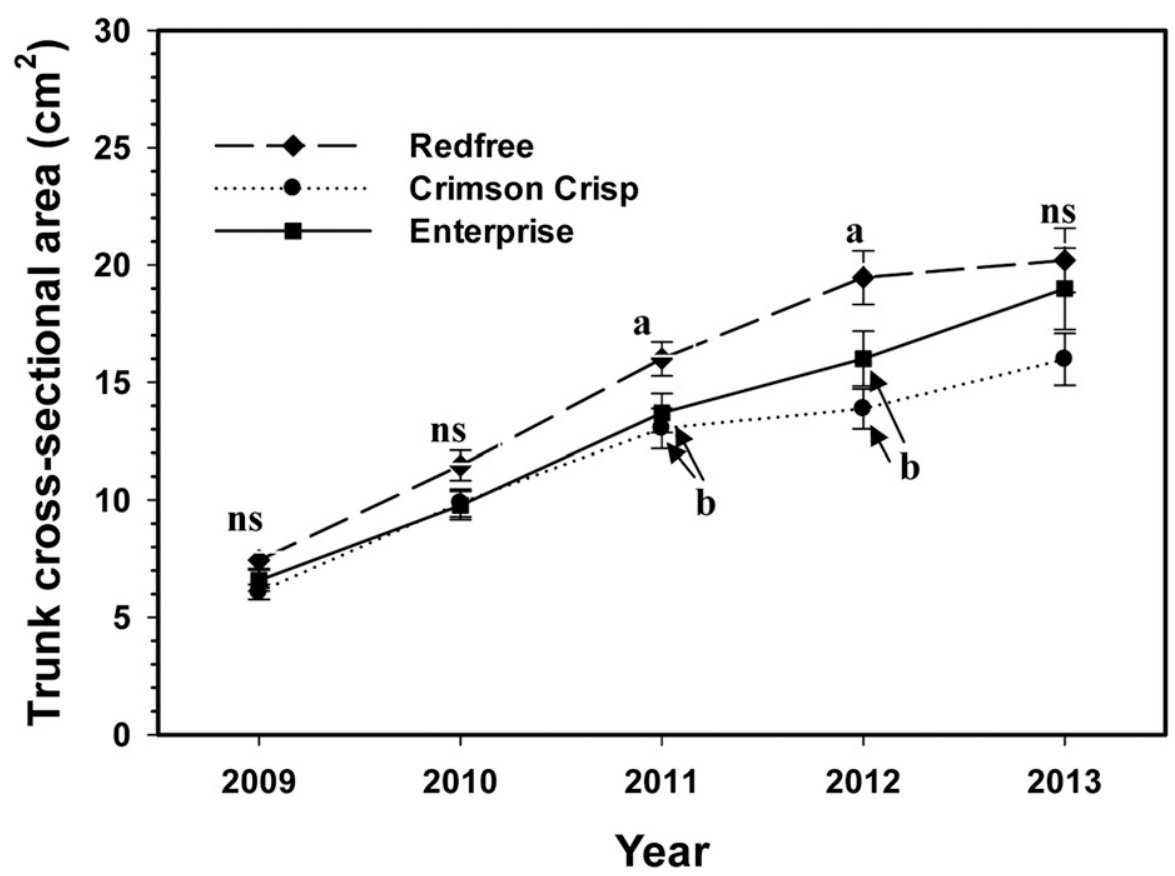

Fig. 2. Mean trunk cross-sectional area $( \pm S E)$ of organically grown 'Redfree', 'Crimson Crisp', and 'Enterprise' apples on B.9 rootstock at the Horticultural Research Farm, Lexington, KY, in 2011-13. The trees were planted in 2007. Values are least squares means, and those within years with different letters are significantly different using the pdiff function at $P<0.05$; Ns indicates no significant difference among cultivars; $1 \mathrm{~cm}^{2}=0.1550$ inch $^{2}$.

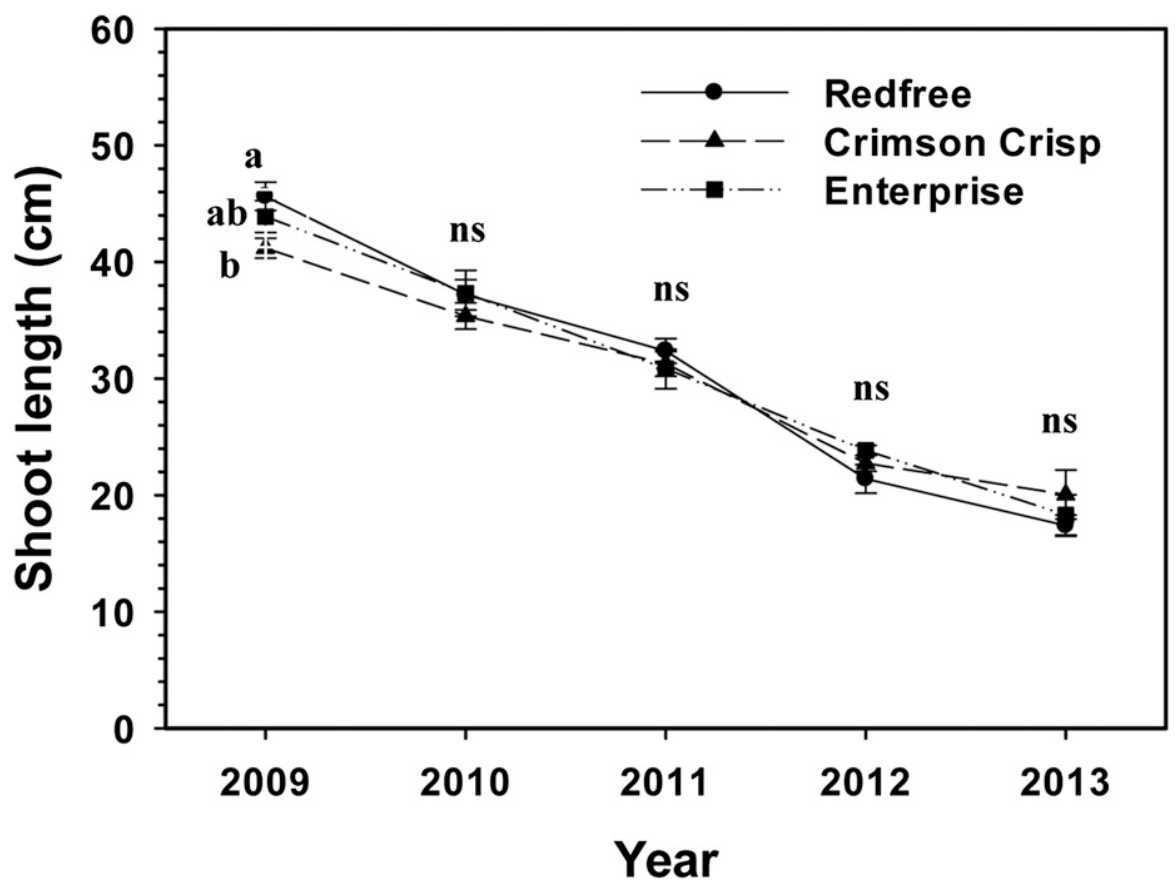

Fig. 3. Mean shoot growth $( \pm \mathrm{SE})$ of organically grown 'Redfree', 'Crimson Crisp', and 'Enterprise' apples on B.9 rootstock at the Horticultural Research Farm, Lexington, KY, in 2011-13. The trees were planted in 2007. Values are least squares means, and those having different letters within a year are significantly different using the pdiff function at $P<0.05$; Ns indicates no significant difference among cultivars; $1 \mathrm{~cm}=0.3937$ inch. 
Tree Growth. Trunk crosssectional area differed among the cultivars in 2011 and 2012. 'Redfree' TCSA was larger than 'Enterprise' and 'Crimson Crisp' (Fig. 2). In contrast, except in 2009, there was no evident cultivar variation in mean shoot length (Fig. 3). Annual growth increments were within the acceptable range of $15-25 \mathrm{~cm} /$ year (Bessin et al., 2011), indicating the $\mathrm{N}$ application rate was appropriate. There was concern that the periodic in-row cultivation may have injured the tree root system and reduced tree growth, but the TCSAs were comparable to those of 'Buckeye Gala' on B.9 rootstock of the same age in an NC-140 rootstock research trial managed by conventional techniques in western Kentucky (Wolfe and Masabni, 2008) and across eight locations in North America (Autio et al., 2011). 'Golden Delicious' on B.9 in western Kentucky and across 12 locations in North America in conventionally managed orchards was also comparable in size (Marini et al., 2009). Stefanelli et al. (2009) did not observe a problem for apple on dwarfing rootstocks with tillage of 5-10 cm for weed management by the Swiss sandwich system, and Polverigiani et al. (2013) found that tillage to $20 \mathrm{~cm}$ resulted in more apple tree root growth below the tillage depth immediately following it, but tillage had no effect on shoot growth.

Fruit THINNING. Liquid lime sulfur plus a fish oil/sesame oil mixture applied each year at the completion of petal fall appeared to reduce fruit per 100 flower clusters, though the apparent effect was quite variable (Table 3). 'Redfree' had the highest fruit set each year. The trees were hand thinning after LLS/FO + SO application to achieve a uniform and consistent initial crop load.

Total yield. 'Enterprise' produced a greater yield than one or both of the other cultivars each year (Table 4). With no comparable conventional planting for comparison, it is difficult to determine an accurate value for an optimum or high yield of these cultivars on B.9 rootstock. However, yields were less than half of the yields of 'Buckeye Gala' and 'Golden Delicious' on B.9 rootstock in western Kentucky and at multiple locations in North America (Autio et al., 2011; Marini et al., 2009; Wolfe and Masabni, 2008). 'Ambrosia' on B.9 in an organic system in British Columbia, Canada, averaged 5-6 $\mathrm{kg} /$ tree at a comparable age (Neilsen et al., 2014), also greater than the present results.

Table 3. Effect of fruit thinning with liquid lime sulfur/fish oil plus sesame oil on the number of fruit per 100 flower clusters of organically grown apples at the Horticultural Research Farm, Lexington, KY, in 2011-13. Data were collected 3 weeks after the thinner was applied.

\begin{tabular}{llccc}
\hline & & \multicolumn{2}{c}{ Fruit [mean \pm SE } & \multicolumn{2}{c}{ (no./100 flower clusters)] } \\
\cline { 3 - 5 } Cultivar & Thinned & $\mathbf{2 0 1 1}$ & $\mathbf{2 0 1 2}$ & Mean \\
\hline Redfree & No & $66 \pm 16^{\mathrm{z}}$ & $157 \pm 18$ & $111 \pm 14$ \\
& Yes & $57 \pm 14$ & $120 \pm 34$ & $88 \pm 17$ \\
Crimson Crisp & No & $27 \pm 12$ & $48 \pm 18$ & $38 \pm 11$ \\
& Yes & $4 \pm 3$ & $22 \pm 13$ & $13 \pm 10$ \\
Enterprise & No & $53 \pm 14$ & $25 \pm 18$ & $39 \pm 13$ \\
& Yes & $30 \pm 16$ & $5 \pm 5$ & $17 \pm 12$ \\
Mean & No & $48 \pm 11$ & $77 \pm 7$ & $63 \pm 6$ \\
& Yes & $31 \pm 9$ & $47 \pm 13$ & $39 \pm 7$ \\
\hline
\end{tabular}

${ }^{2}$ Because of the inability to apply an appropriate statistical design, data were not statistically analyzed.

Table 4. Total and marketable yield per tree, and fruit size of organically grown apples at the Horticultural Research Farm, Lexington, $\mathrm{KY}$, in $2011-13^{\mathrm{z}}$.

\begin{tabular}{|c|c|c|c|c|c|c|}
\hline \multirow[b]{2}{*}{ Yr } & \multirow[b]{2}{*}{ Cultivar } & \multirow{2}{*}{$\begin{array}{l}\text { Total yield } \\
(\mathrm{kg} / \text { tree })^{\mathrm{y}}\end{array}$} & \multirow{2}{*}{$\begin{array}{c}\text { Marketable yield } \\
(\mathrm{kg} / \text { tree })^{\mathrm{x}}\end{array}$} & \multirow{2}{*}{$\begin{array}{c}\text { Proportion } \\
\text { marketable (\%) }\end{array}$} & \multicolumn{2}{|c|}{ Fruit size $(\mathrm{g})^{\mathrm{y}}$} \\
\hline & & & & & All & Marketable \\
\hline \multirow[t]{2}{*}{2011} & Redfree & $2.5 \mathrm{a}^{\mathrm{w}}$ & $1.7 \mathrm{a}$ & $68 \mathrm{a}$ & $117 \mathrm{~b}$ & $122 \mathrm{c}$ \\
\hline & Enterprise & $4.0 \mathrm{a}$ & $1.9 \mathrm{a}$ & $42 \mathrm{~b}$ & $193 \mathrm{a}$ & $204 \mathrm{a}$ \\
\hline \multirow[t]{2}{*}{2012} & Redfree & $1.2 \mathrm{~b}$ & $0.8 \mathrm{NS}^{\mathrm{w}}$ & $64 \mathrm{a}$ & $187 \mathrm{~b}$ & $200 \mathrm{~b}$ \\
\hline & Crimson Crisp & $3.2 \mathrm{a}$ & 1.5 & $46 \mathrm{~b}$ & $131 \mathrm{c}$ & $150 \mathrm{c}$ \\
\hline \multirow{2}{*}{2013} & Crimson Crisp & $3.5 \mathrm{c}$ & $2.1 \mathrm{~b}$ & $58 \mathrm{ab}$ & $147 \mathrm{~b}$ & $155 \mathrm{~b}$ \\
\hline & Enterprise & $8.1 \mathrm{a}$ & $3.4 \mathrm{a}$ & $42 \mathrm{~b}$ & $215 \mathrm{a}$ & $218 \mathrm{a}$ \\
\hline
\end{tabular}

${ }^{2}$ Values are least squares (LS) means. Percentage data were transformed by the arcsine (square root) function for statistical analysis, but untransformed LS means are shown.

y $1 \mathrm{~kg}=2.2046 \mathrm{lb}, \mathrm{l} \mathrm{g}=0.0353 \mathrm{oz}$.

${ }^{x}$ Fruit were considered marketable if they had healed disease or insect injuries covering $<25 \%$ of the fruit surface, had no deformity, exhibited $<50 \%$ russeting, and were $>5.7 \mathrm{~cm}$ (2.25 inches) in diameter.

"Means within columns and years followed by different letters are significantly different using the pdiff function (SAS version 9.3 ; SAS Institute, Cary, NC) at $P<0.05$; NS indicates no significant difference among cultivars. 
Fruit SIZE. 'Enterprise' consistently produced the largest fruit each year (Table 4). However, the thinning effect of the Spring 2012 freeze led to a lighter crop with larger fruit for all cultivars than in 2011 and 2013.

INJURY FROM INSECT PESTS AND DISEASES. Spray applications for insect and disease management were applied on 14,12 , and 11 dates during 2011 , 2012 , and 2013, respectively. The primary insect injury on fruit across years and cultivars was due to plum curculio (Table 5), although injury levels were variable for cultivars across years and among cultivars within years. The exception was that 'Enterprise' fruit exhibited comparable or more injury from codling moth than plum curculio in 2012 and 2013, respectively. Stink bug caused the least injury.

'Redfree' fruit generally exhibited the lowest level of disease symptoms. Cedar apple rust was the major fruit disease on 'Crimson Crisp', and powdery mildew, sooty blotch/flyspeck, and rots were important disease problems for 'Enterprise'. The comparatively low levels of disease problems for 'Redfree' contributed to the higher proportion of marketable fruit for the cultivar as noted above (Table 4).

The proportion of fruit affected by insect pests and diseases in the present study was considerably higher than Friedrich et al. (2003) observed on 'Redfree' in Iowa and Peck et al. (2010) generally found in New York. The lone exception was that in a very wet summer in New York, 68\% of the fruit exhibited sooty blotch/flyspeck, and only $25 \%$ of the crop was free of problems. In addition, Friedrich et al. (2003) found that insect problems increased for Jonafree apple, which is harvested at a later date than 'Redfree', as observed for 'Redfree' vs. the other cultivars in the present work. As in Arkansas (Aselage and Johnson, 2009), plum curculio was the major insect pest, and better control than in this study is essential. However, control of codling moth in 'Redfree' and 'Crimson Crisp' was similar to that in Arkansas when using the same materials for control, although injury on 'Enterprise' was higher.

Foliar lesions from cedar apple rust infection were evident on a variable proportion of the leaves in the 'Crimson Crisp' canopy $( \pm$ SE) $18 \% \pm 1 \%, 16 \% \pm$ $1 \%$, and $31 \% \pm 3 \%$ in 2011,2012 , and 2013 , respectively. In addition, there were $0.26 \pm 0.02,0.93 \pm 0.34$, and $0.50 \pm 0.11$ lesions/leaf in 2011, 2012, and 2013, respectively. Annual examination of 'Redfree' and 'Enterprise' canopies indicated no cedar apple rust problems, results similar to the lower levels of the disease on fruit of these cultivars in 2011 and 2013 (Table 5).

Tree survival. Some tree death was noted in the orchard by 2010 . Injury from vole damage was observed around the trunk base in areas not adequately covered by tree guards. In addition, trunk damage from dogwood borer was discovered beneath the tree guards of weak trees lacking significant vole injury in $201 \mathrm{l}$. Visual inspection of each tree indicated that damage by dogwood borer was not evident following applications of the parasitic nematode $H$. bacteriophora in
2012 and 2013. By 2013, 25\% of the 'Redfree' trees, $28 \%$ of the 'Crimson Crisp' trees, and $11 \%$ of the 'Enterprise' trees in the orchard had died. 'Golden Delicious' on B.9 rootstock showed higher mortality, about $62 \%$, than on several other rootstocks in a conventionally managed orchard in western Kentucky (Marini et al., 2009).

As a result of this study, critical limiting factors to organic apple production in Kentucky were identified. As expected, the major challenges were from the primary insects and diseases known to attack apple, including plum curculio, codling moth, cedar apple rust, powdery mildew, sooty blotch/flyspeck, and bitter rot. Apple scab was not a problem because of the use of scab-resistant cultivars. Weed management under the trees with periodic, shallow cultivation was successful once the lower limbs were pulled up and away from the path of the equipment. However, vole damage continued to be a problem despite cultivation to remove habitat.

Low total fruit yield was a major concern. Although tree growth was comparable to trees on B.9 rootstock in conventional systems, factors reducing total yield need to be determined. Initial fruit set assessed at the time of hand thinning seemed appropriate, but the causes and degree of subsequent fruit drop/loss need to be ascertained. Injury from the most significant pest in the orchard, plum curculio, can cause significant abscission of young fruit (Levine and Hall, 1977). This "lost" fruit, dropping

Table 5. Proportion (as percent of total yield) of organically grown apple fruit with injuries from key insect pests and diseases at the Horticultural Research Farm, Lexington, KY, in 2011-13 ${ }^{\mathrm{z}}$.

\begin{tabular}{|c|c|c|c|c|c|c|c|c|c|}
\hline \multirow[b]{2}{*}{$\underline{Y r}$} & \multirow[b]{2}{*}{ Cultivar } & \multicolumn{8}{|c|}{ Proportion of fruit with injury from insects and disease (\% total yield) } \\
\hline & & $\begin{array}{c}\text { Plum } \\
\text { curculio }\end{array}$ & $\begin{array}{c}\text { Codling } \\
\text { moth }\end{array}$ & $\begin{array}{c}\text { Stink } \\
\text { bug }\end{array}$ & $\begin{array}{c}\text { Cedar apple } \\
\text { rust }\end{array}$ & $\begin{array}{c}\text { Powdery } \\
\text { mildew }\end{array}$ & $\begin{array}{c}\text { Sooty } \\
\text { blotch/flyspeck }\end{array}$ & $\begin{array}{c}\text { Bitter } \\
\text { rot }\end{array}$ & $\begin{array}{c}\text { Black } \\
\text { rot }\end{array}$ \\
\hline 2011 & Redfree & $30.9 \mathrm{NS}^{\mathrm{y}}$ & $15.0 \mathrm{NS}$ & $2.5 \mathrm{NS}$ & $12.6 \mathrm{~b}$ & $2.3 \mathrm{~b}$ & $0.1 \mathrm{~b}$ & $0.6 \mathrm{NS}$ & $0.3 \mathrm{~b}$ \\
\hline & Crimson Crisp & 24.4 & 7.5 & 0.9 & $62.4 \mathrm{a}$ & $23.5 \mathrm{a}$ & $1.1 \mathrm{~b}$ & 0 & $2.7 \mathrm{~b}$ \\
\hline & Enterprise & 30.0 & 12.6 & 2.0 & $7.9 \mathrm{~b}$ & $19.0 \mathrm{a}$ & $24.9 \mathrm{a}$ & 0.7 & $8.2 \mathrm{a}$ \\
\hline 2012 & Redfree & $31.4 \mathrm{a}^{\mathrm{y}}$ & $19.8 \mathrm{NS}$ & $6.2 \mathrm{~b}$ & $0 \mathrm{NS}$ & $10.3 \mathrm{a}$ & $0 \mathrm{NS}$ & $3.9 \mathrm{~b}$ & $3.8 \mathrm{~b}$ \\
\hline \multirow[t]{3}{*}{2013} & Redfree & $19.7 \mathrm{NS}$ & $3.7 \mathrm{~b}$ & $9.4 \mathrm{a}$ & $1.0 \mathrm{~b}$ & $2.4 \mathrm{~b}$ & $5.5 \mathrm{~b}$ & $6.6 \mathrm{c}$ & $2.0 \mathrm{a}$ \\
\hline & Crimson Crisp & 26.9 & $11.1 \mathrm{~b}$ & $3.0 \mathrm{~b}$ & $36.1 \mathrm{a}$ & $18.7 \mathrm{a}$ & $3.5 \mathrm{~b}$ & $14.9 \mathrm{~b}$ & $1.0 \mathrm{ab}$ \\
\hline & Enterprise & 17.5 & $37.3 \mathrm{a}$ & $2.7 \mathrm{~b}$ & $1.3 \mathrm{~b}$ & $27.3 \mathrm{a}$ & $35.3 \mathrm{a}$ & $39.2 \mathrm{a}$ & $0.4 \mathrm{~b}$ \\
\hline
\end{tabular}

${ }^{\mathrm{z}}$ All harvested fruit were examined for signs of insect and/or disease injury; and the number of fruit with plum curculio, codling moth, and stink bug injury; and evidence of cedar apple rust, powdery mildew, apple scab, sooty blotch/flyspeck, bitter rot, and black rot. An individual fruit could display signs of more than one problem, and if so was recorded in each category. Values are least squares means of the untransformed data, though were transformed by the arcsine (square root) function for the statistical analyses. ${ }^{\mathrm{y}}$ Means within columns and years followed by different letters are significantly different using the pdiff function (SAS version 9.3 ; SAS Institute, Cary, NC) at $P<0.05$; NS indicates no significant difference among cultivars. 
after normal June drop and unaccounted for in the final yield data, may constitute the difference between the measured vs. expected yield. The proportion of marketable fruit was generally lower for 'Enterprise' and 'Crimson Crisp' than 'Redfree'. Because the former cultivars ripened at later calendar dates, earlier ripening cultivars such as Redfree may be more desirable in an organic apple system in the midsouth United States. For all cultivars, reductions in plum curculio and codling moth injury are critical for organic apple production in Kentucky to be economically viable.

\section{Literature cited}

Aselage, J. and D.T. Johnson. 2009. From IPM to organic and sustainable agriculture, p. 489-505. In: E.B. Radcliffe, W.D. Hutchison, and R.E. Cancelado (eds.). Integrated pest management: Concepts, tactics, strategies and case studies. Cambridge Univ. Press, New York, NY.

Autio, W., T.L. Robinson, W. Cowgill, C. Hampson, M. Kushad, G. Lang, J. Masabni, D.D. Miller, R.A. Parra-Quezada, R. Perry, and C. Rom. 2011. Performance of 'Gala' apple trees on Supporter 4 and different strains of B.9, M.9, and M.26 rootstocks as part of the $2002 \mathrm{NC}-140$ apple rootstock trial. Acta Hort. 903:311318.

Berkett, L.P., R.E. Moran, M.E. Garcia, H.M. Darby, R.L. Parsons, T.L. Bradshaw, S.L. Kingsley-Richards, and M.L. Griffith. 2012. The OrganicA Project: A multi-state, trans-disciplinary apple research, education, and outreach project. 18 Dec. 2014. <http://www.extension.org:80/pages/ 63325 /the-organica-project:a-multi-statetrans-disciplinary-apple-research-educationand-outreach-project>.

Bessin, R.T., P.S. McManus, G.R. Brown, and J.G. Strang. 2011. Midwest tree fruit pest management handbook. Univ. Kentucky Coop. Ext. Serv. ID-93. 18 Dec.
2014. <http://www2.ca.uky.edu/ acregc/pubs/id/id93/id93.htm>.

Delate, K. and H. Friedrich. 2004. Organic apple and grape performance in the midwestern U.S. Acta Hort. 638:309-320.

Delate, K., A. McKern, R. Turnbull, J.T.S. Walker, R. Volz, A. White, V. Bus, D. Rogers, L. Cole, N. How, S. Guernsey, and J. Johnston. 2008. Organic apple production in two humid regions: Comparing progress in pest management strategies in Iowa and New Zealand. HortScience 3:12-21.

Friedrich, H., K. Delate, P. Domoto, G. Nonnecke, and L. Wilson. 2003. Effect of organic pest management practices on apple productivity and apple food safety. Biol. Agr. Hort. 21:1-14.

Hinman, T. and G. Ames. 2011. Apples: Organic production guide. Natl. Sustainable Agr. Info. Serv., Natl. Ctr. Appropriate Technol., Butte, MT.

Johnson, D.T., B. Lewis, C.R. Rom, H. Friedrich, R. Bryant, and M. Pszczolkowski. 2010. Organic fruit production needs and pest management practices in the southeastern United States. Acta Hort. 873:3744.

Levine, E. and F.R. Hall. 1977. Effect of feeding and oviposition by the plum curculio on apple and plum fruit abscission. J. Econ. Entomol. 70:603-607.

Low, S.A. and S. Vogel. 2011. Direct and intermediated marketing of local foods in the United States. U.S. Dept. Agr., Econ. Res. Serv. Rpt. 128. 18 Dec. 2014. <http://www.ers.usda.gov/media/ 138324/err128_2_.pdf>.

Marini, R.P., B. Black, R.M. Crassweller, P.A. Domoto, C. Hampson, S. Johnson, K. Kosola, S. McArtney, J. Masabni, R. Moran, R.P. Quezada, T. Robinson, and C.R. Rom. 2009. Performance of 'Golden Delicious' apple on 23 rootstocks at 12 locations: A five-year summary of the 2003 NC-140 dwarf rootstock trial. J. Amer. Pomol. Soc. 63:115-127.
Neilsen, G., T. Forge, D. Angers, D. Neilsen, and E. Hogue. 2014. Suitable orchard floor management strategies in organic apple orchards that augment soil organic matter and maintain tree performance. Plant Soil 378:325-335.

Organic Materials Research Institute. 2014. OMRI products list. 1 Mar. 2013. 18 Dec. 2014. <http://www.omri.org/ omri-lists>.

Peck, G.M., I.A. Merwin, M.G. Brown, and A.M. Agnello. 2010. Integrated and organic fruit production systems for 'Liberty' apple in the northeast United States: A systems-based evaluation. HortScience 45:1038-1048.

Perez, A. and K. Plattner. 2013. Fruit and tree nuts outlook: Commodity highlight. Organic fruit and berries. Fruit and Tree Nuts Outlook special article. U.S. Dept. Agr., Econ. Res. Serv. Rpt. FTS-356SA. 18 Dec. 2014. <http://www.ers.usda.gov/ media/1229855/fts-356sa.pdf>.

Polverigiani, S., F. Massetani, D. Neri, A. Perilli, M. Kelderer, and A. Rainer. 2013. Effect of four different soil management techniques on apple root development. Acta Hort. 1001:361-368.

Slattery, E., M. Livingston, C. Greene, and K. Klonsky. 2011. Characteristics of conventional and organic apple production in the United States. U.S. Dept. Agr., Econ. Res. Serv. Rpt. Outlook FTS-347-01. 18 Dec. 2014. <http://www.ers.usda.gov/ media/118496/fts34701.pdfs.

Stefanelli, D., R.J. Zoppolo, R.L. Perry, and F. Weibel. 2009. Organic orchard floor management systems for apple effect on rootstock performance in the midwestern United States. HortScience 44:263-267.

Wolfe, D. and J. Masabni. 2008. Rootstock and interstem effects on pome fruit trees, p. 31-33. In: 2008 Fruit and vegetable research report. 18 Dec. 2014. <http://www2.ca.uky.edu/acregc/ pubs $/$ pr/pr572/pr572.pdf>. 